\title{
Dulwich Hill
}

\section{Chrys Meader}

Dulwich Hill, a suburb of the Marrickville local government area, is located seven kilometres south-west of Sydney. The traditional owners of the land were Cadigal of the Eora nation. The suburb is located on both sides of a ridge, and consists of a number of low hills, which were once heavily timbered. The lower land slopes towards Cooks River and was covered in dense ti-tree scrub.

In the late nineteenth and early twentieth centuries, Dulwich Hill developed as a desirable residential district with a small village shopping centre and isolated but significant pockets of industry. It is a suburb shaped by twentieth-century subdivisions. Dulwich Hill has retained a village atmosphere, even with the late twentieth and early twenty-first century developments where former factory sites have been redeveloped for large apartment complexes. These complexes are themselves small villages within the suburb of Dulwich Hill.

\section{Early European settlement}

Dulwich Hill was part of the land grant to Thomas Moore, who was the colony's shipbuilder. In 1799 Moore received a large grant of 700 acres (283.3 hectares). He called it Douglas Farm. It took in the present suburbs of Marrickville and Petersham and parts of Dulwich Hill and Stanmore. It was the highly prized stands of timber on the estate that most interested Moore and a later owner, Dr Robert Wardell.

Present-day Dulwich Hill also contained a number of smaller land grants, mainly to emancipated convicts. James Bloodsworth (1759-1804), master builder and bricklayer, was a convict on the First Fleet. On arrival he was appointed master bricklayer in the settlement at Sydney Cove. Bloodsworth was largely responsible for the design and erection of Australia's first buildings, including the first Government House in Bridge Street.

Sarah Bellamy (1778-1843) also arrived as a convict on the First Fleet. Bloodsworth and Bellamy lived together and produced seven children.

James Bloodsworth received a pardon in December 1791, the second person emancipated in the colony. In 1794 he was granted 50 acres (20.2 hectares) at Long Cove Creek. A few days later in the name of Sarah Bellamy, Bloodsworth added another 20 acres (8.1 hectares). James Bloodsworth further increased his holdings to 245 acres (99.2 hectares). Bloodsworth Farm and the adjoining Bellamy Farm covered a substantial area of Dulwich Hill between the present Old Canterbury and New Canterbury roads.

Although Bloodsworth was good with the mortar, he was not so good with the money. When he died of pneumonia on 21 March 1804 he was insolvent. Despite his convict origins, Bloodsworth was held in high regard by the community of Sydney. Governor King ordered that he should be given the nearest the colony could provide to a state funeral. The Sydney Loyal Association escorted the cortège with muffled drums, and the body was laid in the Sydney Burial Ground with military honours. 
In the 1820s Dr Robert Wardell (1793-1834), barrister, purchased and consolidated the old land grants into his imposing Petersham Estate. The bush at Dulwich Hill saw many a splendid hunting party chasing Wardell's imported deer towards Cooks River. Wardell was murdered while out riding on 7 September 1834. For many years Dulwich Hill was simply known as Wardell's Bush or Wardell's Hill. This name lasted into the 1890s.

\section{Suburban development}

The first use of the name Dulwich Hill referred to a smaller subdivision of the Dulwich Grove and Dulwich Estate. The subdivisions were named after the London suburb of Dulwich. This may have been in keeping with the London names of the nearby suburbs of Lewisham and Sydenham. Parts of Dulwich Hill, closer to Hurlstone Park Railway Station, were also known as Fern Hill.

Dulwich Hill had good soil and an excellent water supply from small creeks running into Cooks River and Long Cove Creek. By the 1860s market gardening and orchards had emerged as profitable commercial concerns. During the 1870s Sun Hop Yin and his family, along with other Chinese families, cultivated market gardens in Dulwich Hill. Terrace Street takes its name from their style of gardening. There was also small scale brickmaking and potteries.

The name of the suburb as Dulwich Hill took a while to become established. Dulwich Hill railway station was opened on 1 February 1895 as Wardell Road railway station. It was not renamed Dulwich Hill railway station until 1920. Travellers alighting for the first time at Dulwich Hill railway station can get a bit of a surprise as the station is over a kilometre from the Dulwich Hill shopping centre. There is a small shopping centre around the station, which was once better known locally as West Marrickville. It had its own little wooden post office, which doubled as a hardware store and was an agent for a bank.

\section{The ginger beer maker}

The residential development of Dulwich Hill was influenced by several wealthy Sydney businessmen. They were William Starkey, ginger beer and cordial manufacturer, Sir Hugh Dixson, tobacco merchant, and Henry Marcus Clark, founder of the Marcus Clark retail chain of department stores.

In 1838 William Starkey established a plant in Elizabeth Street, Sydney, for the brewing of ginger beer. His larger cordial factory was established about 10 years later in Castlereagh Street, Sydney. This was to become the largest ginger beer factory in the southern hemisphere and Starkey became a household word.

In 1870 Starkey built Gladstone Hall in Ewart Street, Dulwich Hill. Starkey’s estate stretched down to Cooks River where bathing houses were constructed. The Gladstone Hall Estate was subdivided in 1907 into 41 allotments with the larger allotments fronting Cooks River. The house itself was sold on just over an acre (4000 square metres) of land. Two small stone cottages, which Starkey had built for workers, were also offered for sale. 
One of the selling points was the Gladstone Hall Estate's close proximity to both Fern Hill (Hurlstone Park) and Wardell Road (Dulwich Hill) railway stations. Prospective buyers were informed that the journey from estate to station was three minutes and the train journey to Sydney was 14 minutes, giving a grand total of 17 minutes. The walking distance to the stations, mostly uphill, was a bit of an exaggeration or the commuters of the early twentieth century walked very quickly. No time was determined on the distance to the Dulwich Hill tram, which was described as 'handy', although it was a good two- to three-kilometre walk away - also up a steep hill.

The subdivision of the Gladstone Hall Estate opened up this part of Dulwich Hill for residential development. Gladstone Hall retains many of its original features and is a listed heritage item. The sandstone house is rare, as it was built in the Colonial Bungalow style during a period when Victorian Italianate was the more popular style.

Gladstone Hall was purchased in 1958 by Access Industries for the Disabled Ltd (then known as the Civilian Maimed and Limbless Association) which ran it as a hostel until the late 1980s. The building was then taken over by the Sydney Central Health Service. Gladstone Hall, now once again in private ownership, stands on a diminished site backed by unit development. It is the only remaining survivor of the large Dulwich Hill villa estates.

\section{The department store owner}

Fronting Marrickville Road at Dulwich Hill, Henry Marcus Clark (1859-1913) had a property, Sefton Hall, named after the village of Sefton in Lancashire, England where he had grown up. Before moving to Sefton Hall in 1890, the family had lived at Newtown. They would later have other country residences at Mount Wilga, Hornsby, and another Sefton Hall at Mount Wilson in the Blue Mountains.

Sefton Hall had a high brick fence concealing it from view. The Clark children loved to hide behind the fence at dusk and, as people were walking home from work, they would throw a penny tied to a piece of cotton and pull it back quickly. The children would laugh at the sight of someone madly chasing the penny up Marrickville Road.

The property was associated with lavish entertainments and fund raising benefits for the local Marrickville Cottage Hospital. For special occasions Marcus Clark always lit the grounds with Chinese lanterns and fairy lamps.

Sefton Hall was the first private house in Sydney to have a swimming pool, but on 19 January 1907, a relative, Dorothy Gale and a family friend, Edna Kingsbury drowned in the pool. They were both 11 years old. They had been swimming with some of the teenage Clark boys, who thought the girls had left the pool with them and had walked back up to the house. The boys decided to go to the nearby shops in Marrickville Road to buy lollies. It was only when they got back to Sefton Hall that they noticed the girls were missing. The boys ran back to the pool where 14-year-old Will Clark dived in and with the help of the other boys brought the bodies to the surface. Dorothy and Edna could not be revived. 


\section{Dulwich Hill in the 1890s}

In 1890 there was a small but thriving commercial district along New Canterbury Road, Dulwich Hill. The Gladstone Hotel was six years old. There were blacksmiths, butchers, tobacconists, a chemist, a produce store and harness makers. These shops developed around the steam tram and horse-bus terminus.

Steam trams and horse buses provided easy transport to and from Sydney. There was a problem at Dulwich Hill where the authorities constructed a loop to avoid shunting but it was too small and the locomotive engine pulling the passenger tram often jumped the tracks. The old tram loop is now Mallam Reserve and is used as a bus turning circle.

Henry Berghofer, storekeeper and fuel merchant, also ran the Dulwich Hill post office. Berghofer was a member of a well-established local German community, which was in evidence in the area up until the 1950s. Members of this community enlisted as Australians to fight in both World Wars.

As a growing suburb, Dulwich Hill needed a school. A wooden building was opened in Seaview Street in 1885 but proved totally inadequate for the 200 students who enrolled in the first month. A two-storey brick building was erected in 1893. From the top classrooms of the school, now Dulwich High School of Visual Arts and Design, there are excellent views across to Botany Bay. Seaview Street does live up to its name if you can get high enough.

Around the corner in Marrickville Road was a different world of private residences and gardens, including the beautiful Sefton Hall, hidden behind its high wall. In the early twentieth century, Sefton Hall was demolished and the land was subdivided. From this subdivision, several blocks of shops were built along Marrickville Road. The shopkeeper in Marcus Clark would have approved as it did give a boost to the retail life of Dulwich Hill.

Dulwich Hill was a tram terminus, which also assisted in creating the shopping centre. The suburb was serviced by electric trams from 1 April 1900 with trams operating from Circular Quay along George Street to the Dulwich Hill terminus. When the last tram ran to Dulwich Hill on 29 September 1957, it was stopped at Carillion Avenue, Newtown where theological students from Moore College, named for Dulwich Hill's early settler, Thomas Moore, conducted a brief burial service from an elaborate altar placed across the tracks.

\section{The tobacco manufacturer}

Sir Hugh Dixson (1841-1926), tobacco manufacturer, purchased the Abergeldie Estate in 1885. It consisted of 22.5 acres (9.1 hectares) of land and the house. Dixson developed the estate, planting fine gardens with exotic botanical species, and building a hot house, a conservatory, a small piggery, stables, a dairy and later, a garage for his luxury motor vehicle.

Sir Hugh Dixson was a staunch supporter of the scout and guide movement. The Dulwich Hill scout troop was called Mrs Emma Dixson's Own, after his wife. Dixson built a hall for the scouts in Lewisham Street, Dulwich Hill. In 1924 the opening ceremony of additions to the hall was attended by the New South Wales Governor, Sir Dudley de Chair and his wife. A 
large gathering attended the opening with a scout procession up Marrickville Road to Abergeldie, where the Governor's party attended displays by both scouts and guides.

Sir Hugh Dixson died on 11 May 1926 in Colombo, Ceylon (now Sri Lanka). The property and the spectacular collection of objets d'art, furniture and collectables were left to his children. They did not want to live at Abergeldie, which was about 50 years old. The Dixson Trust proposed to demolish all of the buildings on the estate, subdivide the land and auction the house contents.

There was an immediate outcry among local representatives of the community, who formed the Abergeldie Garden Campaign Committee. Support was obtained from the local councils and members of parliament. The Premier of New South Wales, JT Lang, was petitioned to resume the property as a national park.

The Abergeldie Garden Campaign Committee argued that a public garden was urgently needed due to the gradual industrialisation of the area. The well established gardens and trees that existed on the Abergeldie Estate provided a potential park that other places could not achieve in under 30 years. The campaign failed, as did a revised bid for the premises to be developed as a hospital.

The Abergeldie Estate was subdivided and the house demolished. It was the last extensive subdivision in the Marrickville local government area. The subdivision comprised 150 allotments to be offered for sale by Richardson \& Wrench on two successive Saturday afternoons, 20 and 27 October 1928. The opening sale was so hotly contested that the auctioneer, Charles H Crammond, a former mayor of Petersham, sold all the allotments on the first Saturday with the auction finishing by candlelight.

Today the Abergeldie Estate is a major conservation area. It is a fine example of late 1920s and 1930s suburban subdivision. The majority of the purchasers were builders, many of whom were forced to sell their investment lots during the Great Depression. This had an effect on the Estate which can be divided into two periods. The early 1928 and 1929 houses are of a traditional bungalow design and the later 1933 to 1937 houses show restrained signs of art deco, moderne, neo-Georgian and the English Norman influence.

\section{Industries, parks and unit development}

Until the early years of the twentieth century, Dulwich Hill was mainly an area of orchards, market gardens and nurseries. Gelding's Victoria Nursery on Old Canterbury Road was one of the largest until it was subdivided in the 1890s for housing.

The concerns of the Abergeldie Garden Campaign Committee about the gradual industrialisation of Dulwich Hill were well founded. Abergeldie had acted as a buffer. Various potteries and brickmaking works had sprung up close to Abergeldie during the 1880s, including Hart \& Gallagher's Standard Pottery Works and the New South Wales Brick Manufacturing Company.

The main industrial strip developed along the goods line, which opened in 1913. Factories such as the Great Western Milling Company, the Western Timber Mill, and Sidney Williams 
\& Co Pty Ltd in Constitution Road, which made Comet windmills and other engineering products, gained the ability to move their goods quickly and in large quantities. These were very large factory complexes, providing employment to local residents.

The Western Timber Mill was purchased by the Department of School Education and demolished for Dulwich Hill Public School, which opened in 1979. It was the first new school to be established in the inner city for a decade.

Apartments were built on the site of Sidney Williams \& Co in a staggered process, beginning in the mid-1990s and continuing into the early twenty-first century. Other factories were also demolished in the same street with apartments taking their place. The landscaped Williams Parade is a street composed completely of home units and parks. The former industrial estate is totally gone. Around Williams Parade and Constitution Road that the largest cluster of parkland can be found in Dulwich Hill. The Abergeldie Garden Campaign Committee would be satisfied.

Laxton Reserve provides a 'village green' in front of an apartment complex. Johnston Park, which was part of Sarah Bellamy's land grant, also provides 3 acres (1.2 hectares) of open space. Arlington Oval, once several deep disused brick pits, was filled in and converted to recreational use in 1932. During the 1938 British Empire Games, women athletes competed at Arlington Oval. The grandstand was also used in scenes in the Australian movie, The First Kangaroos (1988), about the Australian Rugby League’s first international tour to England.

The Great Western Milling Co, later known as the Waratah Flour Mill, survived to be converted into the Waratah Apartments in 2001. The silos remain a landmark of Dulwich Hill, containing apartments, all with curved windows, and a penthouse silo apartment with 360-degree views. The 80-year old flour mill warehouse was also converted.

Dulwich Hill has a large concentration of units. There are examples from the 1930s onwards with the major era of building occurring during the 1960s. Dulwich Hill was a prime target of developers, and Victorian villas and their gardens were replaced by the standard red brick units all over the suburb.

\section{Schools for girls}

One of the casualties of unit development was Woodcourt College, which was built as a private residence in 1885. It was purchased in 1900 by Mrs Grace Hunt, a widow with a young family who needed an income. A trained teacher, Grace Hunt founded Woodcourt College. In 1919 the College was acquired by the Anglican Church and became a diocesan school with Grace Hunt remaining as principal until her retirement.

The college enrolled both day girls and boarders from kindergarten to secondary level. There were about 150 students. Woodcourt College closed in 1935 with the building being described as 'sadly in need of repair'. The land was subdivided in the late 1940s for housing. Woodcourt College was later demolished for home units.

Grace Hunt was not the only woman in Dulwich Hill to turn her hand to establishing a girls' school. From 1884 to 1899 the redoubtable suffragist, feminist and Federationist, Maybanke 
Anderson, operated Maybanke College on the corner of Wardell Road and Frazer Street, Dulwich Hill. Maybanke Anderson was then the wife of Edward Wolstenhome, failed businessman and alcoholic. He left the family in 1884, shortly after their home, Maybanke, had been built. Maybanke Anderson initially took in boarders before establishing Maybanke College as a girls' school.

Maybanke College had a better fate than Woodcourt. The building was purchased by the Salvation Army as a Home for Aged Females. It remains in use by the Salvation Army as a nursing home.

\section{A couple of premiers and a prime minister}

JT Lang was Premier of New South Wales from 1925 to 1927 and 1930 to 1932. He was also the brother-in-law of the poet, Henry Lawson. In 1896 Lang and Lawson married sisters, Hilda and Bertha Bredt. From 1899 to 1902 they all lived together in Dulwich Street, Dulwich Hill.

Sir Bertram Stevens (1889-1973) became Premier of New South Wales in 1932. He was a member of the United Australia Party. He held the post until 1939. In the 1920s Stevens lived in Woodcourt Street, Dulwich Hill. He was an alderman of Marrickville Council from 1925 to 1928, quitting the position after he was elected Member of the Legislative Assembly for Croydon, when he packed up and moved to Croydon.

John Winston Howard, Prime Minister of Australia from 1996 to 2007, spent a few years of his early childhood in Dulwich Hill. His father, Lyall Howard, owned a service station on the corner of Ewart Street and Wardell Road. The family home, now demolished for units, was situated on the opposite corner. The family later moved across Cooks River to the neighbouring suburb of Earlwood. Howard was well known as a lover of cricket but in his youth he was a keen soccer player taking the field for the Enmore Methodists. Howard's Dulwich Hill connection was often talked about by those interested in analysing his character.

\section{The changing population}

Dulwich Hill is a culturally diverse area. The shopping centre is a reflection of a community made up of people from a large number of ethnic backgrounds, including members of the African, Greek, Italian, Egyptian, Lebanese, Pacific Islander, Portuguese, Chinese and Vietnamese communities.

The Arabic-speaking community has a long history in Dulwich Hill. Sydney's only Egyptian restaurant is in Dulwich Hill. In 1988 the Maronite Sisters established a school, St Maroun's, purchasing the former Carmelite Convent in Wardell Road. They also have a nursing home, next to the school.

British migrants were recruited in the 1960s under a state government trades skill scheme. Dulwich Hill was their first stop in Australia. The Orana Migrant Hostel operated in Marrickville Road from 1962 to 1976. It was a Youth Hostel for many years and is now backpacker accommodation, which adds a bit of an international tourist flavour to the suburb. 
There is a significant Aboriginal population in Dulwich Hill. Aboriginal boxer Ron Richards lived in Dulwich Hill. Richards was an Australian boxing champion in the 1930s, holding the Australian middleweight, light-heavyweight and heavyweight titles. Ron Richards died of a heart attack, aged 56 years, at his Dulwich Hill residence in January 1967. He was buried at Rookwood Cemetery after a service at St Brigid's Church, Marrickville, which was attended by many famous names in the boxing world and by his supporters, both from the Indigenous and the wider community.

Dulwich Hill is a suburban village where people stop for a chat on the main street and the shopkeepers know many of their clientele by name. The large unit complexes have brought more people into the suburb and they have added to the diversity. There has been a growth in artists, academics and writers. The Dulwich Hill Street Fair is held in December in Marrickville Road, spilling around the corner into Seaview Street. Locals come together to celebrate and to create their community.

Chrys Meader is the Marrickville Historian at Marrickville Council in Sydney

\section{References}

Richard Cashman and Chrys Meader, Marrickville: Rural Outpost to Inner City, Sydney, Hale \& Iremonger, 1990

Marcia Clark, Bound to Rise: Henry Marcus Clark \& Sefton Hall, Sydney, Personal Publishing, 1985

Marrickville Council, Abergeldie Estate Heritage Conservation Area; Development Control Plan no 17, 2006

Chrys Meader, Richard Cashman and Anne Carolan, Marrickville: People \& Places, Sydney, Hale \& Iremonger, 1994

Percival Serle, Dictionary of Australian Biography, Sydney, Angus \& Robertson, 1949, available online at Project Gutenberg Australia website, http://gutenberg.net.au/dictbiog/00-dict-biogIndex.html, viewed 26 February 2009

Allan Shepherd, The Story of Petersham 1793-1948, Petersham, Petersham Municipal Council, 1948 